\title{
ANALYSIS OF TIME MANAGEMENT AND SELF- MANAGEMENT WORK PRACTICE BY LEADERS - A FOCUS GROUP STUDY
} \author{
Guba S. u. 40., Hungary \\ Icsapai.gyopar@gmail.com \\ 22dorottyavarga0508@gmail.com \\ 33berke.szilard@szie.hu
}

Erzsébet Gyopár Csapai ${ }^{1}$, Dorottya Varga ${ }^{2}$, Szilárd Berke ${ }^{3}$

${ }^{1}$ Pannon University Zalaegerszeg University Centre, 8900 Zalaegerszeg, Gasparich street 18/A, Hungary

${ }^{2,3}$ Marketing and Management Institute, Szent István University Campus Kaposvár, 7400 Kaposvár,

\begin{abstract}
Nowadays excellent leadership is one of the foundations of high organizational performance. Leadership excellence is a complex topic but efficiency and effectiveness are important components of it. These are closely linked to self-management and time management. In our focus group research, we asked senior executives about how they organize their average workday. We used two theoretical models: the Blue Ocean model and the Franklin Covey time-matrix. According to the participants the key component of effective self-management is the time management. In their leadership practice they often use a digital task manager, a workshop, an informal meeting as a tool and they find knowledge sharing also very important. They try to approach their employees empathetically. They would like to reduce the administrative tasks, spend less time on correspondence, travel and "small talks". They would like to spend more time on automation and communication, further training and team work and dealing with the employees. They think that strategic planning, market analysis, sales, knowledge development and transfer should require more planning.
\end{abstract}

Keywords: leadership, leadership behaviour, time management, Blue Ocean (JEL Code: M12)

\section{INTERNATIONAL STUDENTS IN HIGHER EDUCATION INSTITUTIONS}

The mail goal of our paper was the observation of Hungarian managers in their managerial behaviour regarding their time-management and self-management. The topic is part of a large-scale research containing two steps, a smallscale focus-group study which was the basis of a large-scale questionnaire containing a complex topic about the excellence in business.

Self-management is an important consequence of our commitment in our life - our most basic satisfaction of life - the direct role of how we organize the business of our lives - said (STEENBARGER, 2015) in Forbes magazine. According to (MISCHEL, 1973) self-management behaviour can include personal goals, self-directives for achieving goals, self-administered consequences and plans for self-behaviour. To the question of what influences our self-management (BANDURA, 1969) gave the answer: we usually set standards according to 3 factors. These are criteria on past performance, observed activities of others and socially accepted performance. There is no consensus that self-management is a personality trait or a process; whether it can be learned or a natural endowment. In a broader organisational sense selfmanagement refers to how individuals within the organisation take responsibility for their management activities, such as: planning, scheduling, organisation and control.

The most renowned experts in the topic (MANZ and SIMS, 1980) recommend the following self-management processes if someone wants to be more effective: 
- in the process of self-observation, we continuously collect data about our own behaviour to establish our selfesteem, which will be the basis for our self-affirmation;

- goal definition is another means of self-management. According to (LATHAM and YUKI, 1975) and (LATHAM and LOCKE., 2007) well-formulated goals lead to better performance. Achievement of a goal has high strengthening properties that leads to the setting of additional goals, thereby helping to realize the goals of the organization;

- cueing strategies (stimulus control) - can be described as the gradual restriction of discriminatory stimuli causing bad behaviour; (MAHONEY and ARNKOFF, 1979)

- incentive change - consists of self-esteem-based selfaffirmation and self-punishment. According to BANDURA a self-control individual can strengthen himself as an outsider would reinforce him with supportive behaviour;

- the test - the systematic exercise of achieving the desired performance. (MAHONEY and ARNKOFF, 1979)

Finally, the ability to independently manage our merits and achieve the goals set at the heart of the theory of selfmanagement has not been clarified yet (BERKE, 2010). On the one hand, it is clear that the behaviour of the individual is a primary consideration, but on the other hand it is unclear whether it is a character trait or a process (MARKHAM and MARKHAM, 1995).

We also examined what practical specialists of our time write about self-management. According to business coach Gene Petrov the excellent leader has the following 6 skills of self-management: self-control, reliability, conscientiousness, flexibility, result-orientation and initiative (PETROV, 2020). He and other researchers also write that to become an excellent leader requires selfawareness and self-discipline (PIEROG et al., 2017 ). Dutch researcher and writer (JOOST, 2018) writes about 16 critical factors (Table 1) in the field of successful self-management. They are separated into different 3 organizational levels: individual, team and organizational levels.

Table 1. 16 critical factors in the field of successful self-management

\begin{tabular}{lll}
\hline Individual Level & Team Level & Organization Level \\
\hline Autonomy & External management & Corporate culture \\
\hline Roles & Peer regulation & Corporate policies \\
\hline Driving & Task features & Organizational goals \\
\hline Skills & Team autonomy & Organizational structure \\
\hline Experience & & Training \\
\hline & & Reward \\
\hline
\end{tabular}

Source: Based on (JOOST, 2018)

Self-management must be aware of its role as a supporter at all levels of the organization. Not paying attention to these key factors will almost certainly lead to failure or disappointment. (JOOST, 2018) Finally, management coach (HOKANSSON,
2018) based on her own coaching experience defines the following traits and behaviours as the basis for leadership competence:

- ethics - integrity - credibility

- value-based management

- good time management capability - priority of personal meetings and calendar

- flexibility

- adaptability

- exemplary behaviour

- accessibility - control by walking around

- inclusion

- openness

- diversity champion

- self-care. (HOKANSSON, 2018)

According to (STEENBARGER, 2015) self-management begins with self-talk. Self-talk transforms our own relationship with ourselves; it is also a way of organizing ourselves. At the same time it also draws attention to the contact with our body as our body reacts when it goes deep into some positive activity. In this case a "moral ascension" takes place, in which we activate our struggling, flying, and self-comforting responses. We think of moral ascension as a feeling, but it is rather deep in our physiological response patterns.

When studying the difference between a good leader and an excellent leader (KUREC, 2016) included time management as one of the managerial skills that can be learned to develop. Time management is a skill that has a strong influence on the future of the leader, depending on how he allocates his time. Everyone can improve this skill by following the time that their spends on each activity then calendarizing and examining the amount of it per the different activities (BRIGHT et al, 2019), (BÁCSNÉ BÁBA, 2010), (OPENSTAX, 2019).

However, it is not only that we observe how much time we devote to each activity, but it is also important to categorise different activities in terms of importance and urgency. In COVEY'S book of 7 habits this appears as a tool, as the third habit like a quadruped matrix. It was introduced into the public awareness on the basis of the decision support principle of former US President EISENHOWER and has been popular in both management and marketing since then. The principle is to divide tasks in order of urgency and importance with the aim of optimizing the timetable (MFONDOUM et al, 2019).

KIM and MAUBORGNE reconsidered the method and developed the Blue Ocean framework, a market space strategy without any competition, which refers to the blue ocean as a space of endless possibilities as opposed to the red ocean, which is the "stressful" current market space (KIM and MAUBORGNE, 2005). The essence of the Blue Ocean business model is to get the non-consumers become interested in the product instead of concentrating to the competitors. This strategy encourages us to break up with old habits and involve new elements. The strategy is not a 
theoretical model, it was developed on the basis of the study of "best practices". The strategy was started to be applied by many and these were studied for example by (LEAVY, 2018), who examined the process of innovation and the practical application of this strategy or (KOMULAINEN and SILTALA, 2018) studied the common motivation for success/failure of Western cooperative consumers in the twentieth century.

(SAKAR and SÜRÜCÜ, 2018) investigated augmented reality in the industry, the applicability of an element of the Blue Ocean strategy in the maritime industry. One of the analytical tools of the Blue Ocean Strategy is the 'four action framework', "a method of defining a business strategy that 'simply' means asking and answering questions about the consumer value factors, what the industry has taken for granted, which one's could be reduced and increased and finally what new factors can be created in addition to what industry has ever offered. Strictly speaking the four action framework is mostly a principle; the principle is that these four questions must always be asked by those who want to create a blue ocean and the answers must be carefully considered" (GYURKÓ, 2009). Within the framework of this thought a net of "cut-down-increase-create" matrix was prepared, which was filled by the leaders who participated in our research. When we installed the model into the field of leadership and management practice an article by (CHAN and MAUBORGNE, 2014) was considered to be authoritative.

\section{MATERIAL AND METHOD}

The "Leader`s Habits" research team of the Kaposvár University led by associate professor Szilárd Berke under the project EFOP-3.6.1-16-2016-00007 NK2 entitled "Leadership practice in small and medium-sized enterprises and startups success-thinking and marketing strategy decisions" has carried out research on the topic between September 2017 - February 2019. The aim of the research was first to map managerial 'success thinking' - how leaders thinking about themselves, their company and some corporate key processes and second to examine value-creating processes and looking for good practices. The research analysed at least six different areas inside the wider topic. The whole research was characterized by exploratory 'pilot' nature, since no validated questionnaire could be found in the chosen contexts that would have analysed both the designated dimensions (BERKE, 2019).

The aim of the research was to explore a general picture of the situation, to establish a "diagnosis", which could be a base later for a national research. Because of this, neither randomness nor representativeness was our goal, and qualitative research has been bearing nearly the same weight in the evaluation of the results as the quantitative procedure.

\section{Methodology of the focus group research}

Within the framework of the project two-step studies were carried out, on the one hand a series of focus group interviews, which were conducted both in Hungary and among Hungarian entrepreneurs in Transylvania, as well as a questionnaire study. Within the framework of this article we will select from the results of the first phase.

As a framework for the pilot research we organized 10 focus groups - 5 in Hungary and 5 in Romania (especially: Szeklerland) at different locations - with leaders in the SME sector. Finally, the data contains responds of 44 managers. The focus group interviews were taken place in January-May 2019. The participants of the focus group interviews were contacted and organized based on the personal relationships of the research group. Two to eight people gathered at one location with, whom we conducted a one and a half hour to two hours of conversation. More than 19 hours of interview materials were prepared which typically had to be listened to two, sometimes three times in order to obtain all of the information from the recordings. Among the projective research techniques, the scenario included association games, card games, self-assessments and tests. It consisted of four pages, which of two were test sheets based on various models ( (COVEY, 2014); (CHAN and MAUBORGNE, 2014).

In order to process the data, we partly used the qualitative data analysis system nVivo. The advantage of the nVIVO data analysis program is that it allows the hierarchy of categories and the control of hypothetical conceptual structures (SZOKOLSZKY, 2004).

\section{RESULTS AND DISCUSSION}

\section{Daily habits and self-management practices}

The question was here: what they do every day to make the business more efficient in the market. Our goal was to find good practices, proven ideas that have worked and which could help to others in the future. In terms of good practices, the technical support-backed task management systems and conscious communication were common. Among the answer we have highlighted those that seem effective or can serve as thought provoking.

\section{(1) Communication, task manager, unbound working hours}

"I introduced a task management online system with which I have replaced the long and time-consuming conversations, so everyone knew their daily tasks and even the next 10 days' and long distance tasks. Therefore, I had time to observe what communication was like inside the organization and I noticed that within a certain period of time the appearance of the classic situations that disturb me. When I see this, I tell them to talk to each other to make it work because of the aim. That is my approach but as I see my colleagues like it too - in terms of efficiency- that I give them enough free time. I am interested in the results, not the performance. I used to say that one can show performance with zero results. For example, someone might work a lot while moving the earth from one pit to the other pit, but the work doesn't make any sense. Rather I assign as much tasks to the organisation that 
have to be done and the deadline of everything is that what really matters. For me, that is the principle... everyone can reach the server from home, so you can work on Sundays, the point is, if I say I need it on Monday, I want it to be done by Monday. I give this kind of freedom to everyone, there are colleagues who use it and there are colleagues who are effective then if they keep themself very rigidly on working hours. This is an opportunity to everyone. I saw results in this, helping the systematization technically and paying attention to communication and giving this degree of freedom bring results. The name of the program what we use is Just Do and it is made by a company from Kaposvár, it can be operated at quite a low cost. Nevertheless, we are developing one of our own now." (Project Office - Municipal Company)

"We also have a task manager because there are routine tasks that it manages on a daily, monthly, quarterly basis because the area is large to be covered and there are so many places you need to pay attention to. It is a program of our own. Individual tasks are essential and we review them alternately to see if the colleagues have entered any problems or deficiencies because we could find problems all the time. It is my way of measuring that there were undiscovered areas or not. On the other hand, you have to constantly walk around the entire work area. Besides of these, I walk around, though not on a daily basis but weekly to see how our employees are doing." (Farm - Contractor)

"There are times when I wake up at night and I think of an idea that I dictate to my phone. We are lucky to have my daughter as the office manager and they have weekly meetings to discuss the problems. We also hold 10 minutes of brainstorming of the given tasks. I think our employees are diverse and their problems need to be handled. There are three-five more important points that you should always pay attention to. We cannot make plans because of the numerous changes in the business, 60-70 percent of our work is incalculable." (Distribution Centre - Food Industry)

(2) A highly active and committed middle manager seeks to increase the efficiency of the company through creative practices motivate and develop the employees.

"For me, my life consists of keeping people and making them willing to work with me. We have given the amount of work that needs to be done. There is a bit of variation, but you have to work with them all the time. We have a weekly meeting about informing them of the current events; lack of the information is typical in the organizations. Usually nobody knows anything. I always tell what I doing today and tomorrow, on the other hand, everyone tells me what he does. If they need help, they can indicate it here. At the end of the discussion everyone gets all of the information about that what the others do at the workplace. It is a regular and important leadership tool.

There are also informal meetings: joint meals and joint pancake afternoons where these issues come up and we can talk about it. These are weekly in the form of breakfast or lunch by setting the table in the conference room. Now we are going to have a yoga class once a month for our colleagues because there is a big demand for this before working hours and it looks like we can even have funds for it. We have a professional day once a month. I hear about a lot of free conferences at the university and I always send someone to participate on it, who can tell us what they have learned. It is knowledge sharing. There is also a cookie contest on this day, so everyone bakes something, usually boys win. What I still do and I like is that I organize the different methodologies that appear in the form of a workshop. For example, the Social Photo Matrix, which is about mapping the subconscious about how someone feels at the workplace. Every colleague had to take a picture of how he/she felt here. At the workshop the images are projected and each photo can only be seen for 20 seconds and you need to associate an idea. Someone collects them, it is partly unconscious, so no one can think, we just have to throw words in, and then we try to figure out what this shows us about the organization itself. Another is the "dispute workshop"; it is a methodology about how to argue without hurting the other. Now there is a regulatory change that calls into question many things what we do. For us the question is that, is there a life after the regulatory change and what we have to do. For this there is also a board game available. Every month or every 2 months, I try to come up with something new to make them feel a little better, because it's hard to work for global companies over long periods." (Financial institution-Multinational Corporation).

"My new business is focused on networking; I need to establish new connections so I write contact lists every day, collect contact information, make calls, which is one of my weaknesses. I don't like phone calls, and I'm still practicing." (Social sphere-NGO)

(3) In start-up businesses, full dedication, engagement and momentum are strongly felt:

"I read 2 hours a day, I listen to YouTube videos 2 hours a day at a speed of $2 x$, I deal with the company around 100 hours a week. One can work like this for a while, this is Elon Musk's 100-hour work week, but it does have its consequences." (Start-up Company)

(4) Several managers highlighted the importance of personal relationships when communicating with colleagues:

"For me,which worked as a daily routine, which is by instinct a daily routine by the way, is that I call everyone by his/her name. So, if I say hello, for example: Hi, Balázs, I will add your first name. I mean, I often say their names because they like to hear it. However, I am not saying this because I am trying to achieve a goal when I am saying hello. I like to they know it is for them. I do this every day. I mean, what I always put next to, which I am not slothful to add, "How are you?"; "You're pretty!"; "How beautiful your hair is!" etc. So, I throw one more praise. For me this is my daily routine." (Manufacturing Industry-Multinational Company)

"I start the day with "What's up?" I go to the office in the morning and walk around every office to see what is going 
on. It rather relaxes the mood, I think. This "What's up?" is a daily morning routine that I practise to relieve the tension a little. Besides, I have been dancing Charleston lately. While I was working in a bank it was a daily routine of getting in the middle of the place and show off a Charleston because we were under a lot of pressure because of the big kick-off meetings in the mornings. This is a very important thing. It is not just discussions, meetings, day launchers, day closing, weekly, Wednesday, Friday meetings, they mean much more to me sometimes. Because this "What's up?" might start a conversation in the office that might not occur in a meeting." (Service industry-Multinational company)

"I don't have a daily routine, but I do have a routine. And it makes it so much easier to eliminate the word daily. Routine means for me the customer visits and the maintain personal relationships at stated intervals, at least once a month. I try to reach everyone in every month because it does matter. E-mail, phone calls, etc. are not enough, you have to go to lunch, discuss not only the work, but also private issues. Which we do not write down. And the other thing is, there is a chance that if something doesn't work out, we can talk about it. Sometimes you look at the results either at work or in the enterprise and you see if you are going where you are supposed to go and if you do not than you can discuss what is that you should to do differently. We need guidance on the one hand and an example on the other. That someone needs to pull you and pull the others, and that is a leadership task." (Furniture Production - Multinational Company)

\section{Appearance of the "Blue Ocean" strategy among executive working methods}

Following the Blue Ocean Strategy model, we filled out a test form, and the related question was: What actions and activities would you stop to run the company more effectively? What would you increase? What would you allocate less time to? What kind of activities would require more planning?

Out of the 44 sample (Table 2), 12 people do not want to eliminate any of their current activities in order to increase effectiveness, 4 people do not want to reduce, and interestingly 2 people do not want to create a new one or do not want to include more planning.

The received answers could be summarised as follows: more people would like to reduce administration, bureaucracy and there was one person who would like to eliminate it altogether. The other activities, which several respondents would like to reduce are the time spent on unnecessary correspondence, communication and time that they spent on travelling, both of it in terms of efficiency and time management. If you look at the other answers among the activities to be eliminated or reduced, you can see that the aim of all is to better utilize the time factor and increase efficiency. The number and standard deviation of activities to increase are the largest that we could be grouped together as: increase self-improvement, self-efficiency (such as reading professional books, attending conferences), developing staff and increasing their efficiency, strengthening teamwork and improvement of working conditions, increasing working mood and motivation, and only a few thoughts related to specific marketing and acquiring activities. Among the activities that need more planning are especially the longer-term plans and more specific activities that are related to the strategy.
Table 2. Blue Ocean Strategy - Four Action Frame Answers $(n=44)^{2}$

\begin{tabular}{|c|c|}
\hline I would like to eliminate it & I would like to spend less time on it \\
\hline $\begin{array}{ll}- & \text { administration }(n=3) \\
\text { - } & \text { bureaucratic tasks }(n=2) \\
\text { - } & \text { time consuming activities }(n=2) \\
\text { - } & \text { that I have to do everything } \\
\text { - } & \text { that I could be the solution to } \\
\text { everyone } & \text { workplace gossip } \\
\text { - } & \text { first round job interviews } \\
- & \text { travel } \\
- & \text { customer service } \\
- & \text { overtime } \\
- & \text { compliance with state institutions } \\
- & \text { negative relationships }\end{array}$ & $\begin{array}{ll}\text { - } & \text { administration }-(n=8) \\
\text { - } & \text { reading and replying to non- } \\
& \text { relevant emails }-(n=4) \\
\text { - } & \text { travel }-(n=3) \\
\text { - } & \text { small talk }(n=3) \\
\text { - } & \text { time consuming persons }(n=3) \\
- & \text { occupational safety }(n=2) \\
- & \text { dealing with uncalled problems } \\
- & \text { worrying } \\
- & \text { answering questions that don't } \\
& \text { necessarily need me } \\
- & \text { long meetings } \\
- & \text { multitasking } \\
- & \text { external information } \\
- & \text { customer service } \\
- & \text { routine work } \\
- & \text { Labour Control }\end{array}$ \\
\hline
\end{tabular}

I would like to increase it I would like to put more planning into it

specialist training $(n=4)$

delegation $(n=2)$

automation processes $(n=2)$

communication efficiency $(n=2)$

teamwork $(n=2)$

my free time $(n=2)$

personal or telephone

communication $(n=2)$

marketing effectiveness

the effectiveness of controlling

the team dynamics

number of customer visits

my own commitment, my

courage to invest in the future

product portfolio

occasion and time of personal encounters

number of Facebook shares

participation in conferences

teleconferences

time spent with colleagues

telework

regular lunches with staff

supervision of company

expenditure

personal training plan

sales efficiency

decision-making of employees

training myself and my people

strategic thinking

require the achievement of the goals -

efficiency, productivity

GTD (How to get started)

recharge time

establishment of relations

acquisition

reading textbooks

conversations and feedback

with colleagues

the time devoted to creating

in the preparation of strategic

decisions $(n=4)$

into market analysis, databases $(n=3)$

image design $(n=3)$

online marketing $(n=2)$

into financial planning - $(\mathrm{n}=2)$

into knowledge upgrade $(n=2)$

exploitation of technical

possibilities

working in advance

more thorough development of themes

selection of colleagues

transforming working conditions to make work more creative

compliance with new regulations business line - 4DX system

categorization of important and urgent, important, but not urgent, urgent, but not important, nonurgent and unimportant tasks promotions, events

competence increases at managerial level teach all employees to research and implement continuous efficiency-enhancing elements in their work

a vision created together with colleagues

automation potential

prioritization

sales

contact lists training

client connection

international relations

logistics

exploitation of research and development potential

team development

added value

the verifiability during

implementation

transparency of information

Source: Interview transcript 


\section{CONCLUSIONS}

Regarding time management - examining Covey's habit 3 table - we found that the highest rate is in the 2nd quadrant (quadrant for strategic thinking, planning). The executives spend most of their time in the important but non-urgent quadrant, which is an important characteristic of excellent leaders, based on the literature. Based on the Blue Ocean model reshaped into the field, the majority of leaders participated in the research want to reduce administration and bureaucracy. Activities that need to be reduced by several respondents are also: unnecessary correspondence, travel (to work). Delegation skills also return here as an area for improvement. The respondents clearly aimed to make better use of the time factor and increase personal efficacy. Management activities that should be devoted to more time can be divided into several areas, such as: self-improvement, increasing one's own efficacy (for example: reading textbooks, attending conferences); developing employees and increasing their personal efficacy. Furthermore, strengthening teamwork and improving working conditions, increasing work ethic and motivation. These are characteristic of a leader who wants to develop himself to be able and willing to step out of the usual framework and think innovatively and creatively. In summary, according to our research, the leading managers of smaller companies are aware when it comes to time management and self-management - in this point of view they are probably not lagging behind the leading managers of multinational companies. Their daily practice is advanced and up-to-date. The results of the research effectively contributed to the compilation of a questionnaire to examine these areas at the country level as well.

\section{REFERENCES}

Bácsné Bába, É. (2010). Az időtényező szerepe a tartalmi vezetési feladatokban. A Virtuális Intézet Közép-Európa kutatására Közleményei, (2)3-4, pp. 126-133. http://acta. bibl.u-szeged.hu/id/eprint/30088

Bandura, A. (1969). Principles of behavior modification. New York: Rinehard \& Winston. ISBN-13 : 978-0030811517

Bányai, E., \& Sipos, N. (2019). Aktualitások a felsővezetôi kiválóság területén. Vezetéstudomány, 63-69. https://doi. org/10.14267/VEZTUD.2019.01.06

Berke, S. (2010). In: Lifelong, Learning Magyarország Alapítvány (szerk.) Tanulás, tudás, gazdasági sikerek avagy a tudásmenedzsment szerepe a gazdaság eredményességében (Az életkerék és a TLS életstílusmodell szerepe a személyes hatékonyságban. pp.:357-359). Komárom: Lifelong Learning Magyarország Alapítvány.

Berke, S. (2019). Kutatás a stratégiai szemléletú vezetésről. https://leadershabits.wordpress.com/publications-2/. HR Portál.
Bright, S., Cortes, A., \& Hartmann, E. (2019). Principles of Management. USA: 12th Media Services. ISBN-13: 9781680922899

Conger, J., \& Kanungo, R. (1987). Toward a behavioral theory of chraismatic leadership and organizational settings. Academy of Management Review, 634-647. https://doi. org/10.5465/amr.1987.4306715.

Covey, S. R. (2014). A kiemelkedően eredményes emberek 7 szokása - Az önfejlesztés kézikönyve . Budapest: Bagolyvár. ISBN: 9786155030437

Dekntas Sakar, G., \& Sürücü, E. (2018). AUGMENTED REALITY AS BLUE OCEAN STRATEGY IN PORT INDUSTRY. Dokuz Eylül Üniversitesi Denizcilik Fakültesi Dergisi, 10(1), 127 - 153. DOI: 10.18613/deudfd.428196 Gergely, É., \& Pierog, A. (2018). A tehetség megtartásának lehetőségei a karrierigények tükrében. International Journal Of Engineering And Management Sciences / Múszaki És Menedzsment Tudományi Közlemények, (3)3, pp. 31-43. https://doi.org/10.21791/IJEMS.2018.3.3.

Gyurkó, G. (2009). Szervezéstechnológia. Budapest: BGK PSZK.

Hokansson, S. (2018a). The Importance of Self-Management for Leaders. Source: http://www.thestaffingstream. com/2018/11/05/the-importance-of-self-management-forleaders/

Joost, M. (2018). The Science of Successful Self-Management: 16 Crucial Factors. Letöltés dátuma: 2020. 05 25, Source: corporate-rebels.com: https://corporate-rebels.com/selfmanagement-crucial-factors/

Kim, W., \& Mauborgne, R. (2005). Blue Ocean Strategy. Harward Business Review, 82(10), 76-84.

Komulainen, A., \& Siltala, S. (2018). Resistance to Inequality as a Competitive Strategy? - The Cases of the Finnish consumer Co-ops Elanto and HOK 1905-2015. Business History, 60(7), 1082-1104. https://doi.org/10.1080/0007679 1.2018.1494729

Kurec, A. (2016). Follow the Leader: Developing Great Leadership Skills. Critical Values, 9(4), 24-27. https://doi. org/10.1093/crival/vaw024

Latham, G. P., \& Locke., E. A. (2007). New Developments in and Directions for Goal-Setting Research. European Psychologist, 12(4), 290-300. https://doi.org/10.1027/10169040.12.4.290

Latham, G., \& Yuki, G. (1975). A review research on the application of goal settings in organizations. Academy of Management Journal, 18(4), 824-845. https://doi.org/10.5465/255381 
Leavy, B. (2018). Value innovation and how to successfully incubate "blue ocean" initiatives. Strategy \& Leadership, 46(3), 10-20. DOI: 10.1108/SL-02-2018-0020.

Mahoney, M., \& Arnkoff, D. (1979). Self-management: Theory, reserach and application. In J. Elrady, \& D. Pomarleau, Behavioral medicine: Theory and practice (old.: 75-96). Baltimore: Williams\&Williams. DOI: 10.1207/ S15324796ABM2601_01

Manz, C., \& Sims, H. (1980). Self-Management as a Substitute for Leadership: A Social Learning Theory Perspective. Academy of Management Review, 5(3), 361-367. https://doi. org/10.5465/amr.1980.4288845

Markham, S., \& Markham, I. (1995). Self-Leadership reexamined: A levels-of-analysis perspective. Leadership Quarterly, 6(3), 343-359. https://doi.org/10.1016/10489843(95)90013-6

Mischel, W. (1973). Toward a cognitive social learning reconceptualization of personality. Psychological Review, 80(4), 252-283. https://psycnet.apa.org/doi/10.1037/h0035002

Ngadam Mfondoum, A. H., Tchindjang, M., Mefire Mfondoum, J. V., \& Makouet, I. (2019). Eisenhower matrix * Saaty AHP=Strong actions prioritization? Theoretical literature and lessons drown from empirical evidences. IAETSD Journal for Advanced Research in Applied Sciences, 6(2), 13-27. ISSN NO: 2394-8442

Openstax. (2019). Principles of Management. Houston, Texas: Rice University. ISBN-13: 978-0-9986257-7-5

Petrov, G. (2020). Self-management skills. Downloaded: 2020. 05 25, source: ldrbrnd.com: https://ldrbrnd.com/selfmanagement-skills/

Pierog, A., Bácsné, B. É., \& Dajnoki, K. (2017 ). Sikeres vezetők tulajdonságainak feltárása a Debreceni Egyetem Gazdaságtudományi Kar hallgatói körében végzett kutatás eredményei alapján. Taylor: Gazdálkodás- és szervezéstudományi folyóirat: a virtuális intézet közép-európa kutatására közleményei , 9(1), 94-100. ISSN 2064-4361.

Steenbarger, B. (2015. 5 15). Forbes. Forrás: https://www. forbes.com/sites/brettsteenbarger/2015/05/15/self-leadershipand-success/\#39f2e3ad2a81

Szokolszky, Á. (2004). Kutatómunka a pszichológiában. Budapest: Osiris Kiadó. ISBN: 963-389-682-7

W Chan, K., \& Mauborgne, R. (2014). Blue ocean leadership. Harvard Business Review, 92(5), 60-8, 70, 72 passim. PMID: 24956870 
